\section{LIBRARIANSHIP TRAINING}

The Institute Program for Librarianship Training is authorized by the Higher Education Act of 1965, Title II-B. The purpose of the Institute Program is to provide opportunity throughout the nation for upgrading and updating the competencies of persons serving all types of libraries, information centers or instructional materials centers offering library type services and those serving as library educators.

An institution of higher education which has an established library education program or is planning to begin such a program in the academic year 1969-70 is eligible to apply for funds to conduct an institute during the summer of 1969 or during the academic year 196970. Institutes must supplement rather than be a substitute for an existing librarianship training program.

Although funds have not been appropriated for fiscal year 1969, institutions have been invited to express interest and intent to submit proposals for library institutes. The Policies and Procedures Manual to be used in the preparation of proposals will be sent to the designated authorized official as soon as possible after the expression of interest has been returned. It is anticipated that the deadline date for submitting proposals will be October 15 , 1968.

\section{NATIONAL LIBRARY SERVICE}

A new British National Library Service should be a direct responsibility of the government and administered as part of the Department of Education and Science, says the $\mathrm{Li}$ brary Association in evidence it has submitted to the Dainton Committee, set up by the government to study the problem of a national service.

The association says that the library departments of the British Museum should be divorced from the antiquities departments. These library departments, the national central library, the national lending library for science and technology-together with the British national bibliography, the copyright offices and a new national bibliographical and information service-should together form the new National Library Service.

It would have two principal divisions, one as a national reference library and the other as a national lending library. It should be directed by a professionally-experienced directorgeneral, with a status not less than that of a deputy secretary in the Civil Service.

To advise the Secretary of State, the state- ment goes on, there should be a library services council and within the Department of Education and Science there should be a libraries branch. The service should recruit staff with appropriate academic and professional training and should make some contribution to professional training at an advanced level.

The association argues for a site in central London for the National Reference Library and the bibliographical headquarters of the $\mathrm{Na}$ tional Lending Library, adding that the site area of seven and one-half acres envisaged by the British Museum trustees would not be excessive.

Among the many other detailed recommendations are that the national libraries of Scotland and Wales and the university libraries at Oxford and Cambridge should be brought into relationship with the National Library Service, but that it should not include the Science Museum library; and that the reference library and the Public Record office should be housed close together and a national policy on archive collection formulated.

\section{LIBRARIANS OF PUBLIC HIGHER EDUCATION}

At a meeting of the Council of Massachusetts State College Librarians at Provincetown on May 10, attended by representatives from the libraries of the state colleges, community colleges, Southeastern Massachusetts Technological Institute, the University of Massachusetts in Boston, and addressed by Richard $\mathrm{M}$. Millard, chancellor of higher education for the Commonwealth, it was decided by unanimous action of the librarians present to form a group to be known as the Massachusetts Conference of Chief Librarians of Public Higher Educational Institutions. The group was formed in response to Chancellor Millard's presentation of the problems facing the libraries in those institutions, and the discussion which followed. The conference will meet at least three times a year, and its mission will be to identify problems common to all the libraries and to perform appropriate research in order to bring forth recommendations for their solution.

The recommendations will be presented to the councils of the state college and the community college libraries, and to the technological institute and university library staffs for their approval and adoption. It is hoped that out of this action will come a handbook of recommended standard library practices which will help the individual libraries solve some of the problems outlined by Chancellor Millard and the discussants. Some of the most pressing problems concern the building of adequate basic book collections in the public ed- 